\title{
Evaluation of Taxa for Tolerance against Floral Malformation in Gangetic West Bengal
}

\author{
Kalyan Chakraborti, Dilip Kumar Misra* \\ Directorate of Research, Bidhan Chandra Krishi Viswavidyalaya, Kalyani-741 235,Nadia, West Bengal \\ *Corresponding Author: dkmbckv@gmail.com
}

Copyright $@ 2014$ Horizon Research Publishing All rights reserved.

\begin{abstract}
Mango (Mangifera indica L.) the king of fruit is succumb to attack of many pathogens causing various diseases. The crop is vulnerable at all of its growth stages starting from seedling to fruit maturity even at post harvest stage during storage, transit and marketing. Among several diseases affecting the crop, powdery mildew, anthracnose and malformation cause economic losses. As the host resistance is compatible with other methods of control, therefore, this verdict may guide the orchardists to develop an integrated disease management programme. Keeping this in view, a survey was carried out in Gangetic West Bengal during the year 2004 to 2006, and screened twenty varieties of mango of three to five years bearing plant for tolerance against floral malformation. Susceptibility rating was done using 0 to 5 scale and the host-taxa were classified to their response to the pathogen. It was found that among the taxa, Mallika was recorded to be the most susceptible against floral malformation and Kishan Bhog was the least. The order of susceptibility of mango varieties to floral malformation in descending order was Mallika, Kesar, Suvarnrekha, Dashehari, Alphonso, Chousa, Neelum, Bangalora, Mulgoa, Vanraj, Himsagar, Fazli, Fernandin, Langra, Baneshan, Mankurad, Bombay Green, Zardalu, Bombai and Kishan Bhog.
\end{abstract}

Keywords Mango Malformation, Plant Reaction, Susceptibility Rating

\section{Introduction}

Mango (Mangifera indica L.) is vulnerable to a count of diseases at all phases of growth, convenient from seedling in nursery to fruits in maturity and storage. Hardly any plant part is free from diseases. They not only reduce the yield but sometimes account for a complete crop death. Disease affects flowering, fruiting and also timber production. Some of the diseases directly damage the fruits, and others affect the growth and physical development. Of the several pathogens that are causing diseases fungi have the leading place. Among several diseases affecting the crop, powdery mildew, anthracnose and malformation cause meaningful and significant loss of the crop. The mango malformation was first reported from India by Watt in 1891 and associates to the abnormal growth of plants or plant parts. Mango floral malformation may cause as high as 80 per cent yield loss by affecting panicle (Ginai, 1965). Earlier malformation (Fusarium moniliforme var subglutinans Wollenw and Reink) was thought to be a disease of Northern India (Rao, 1983) but lately noticed in Gangetic West Bengal also (Chakraborti, 2006). This malady manifests in two forms viz. Vegetative malformation and floral malformation. Floral malformation is the most serious disease; rendering mango cultivation non-lucrative in subcontinent and other regions of the world (Ahmad el al., 2002; Ploetz, 2001). In floral malformation dimination in the length of primary axis and the secondary branches of the panicles makes the flowers appear in clusters. The blooms remain as dull green, unopened and persistent buds. Even the fruit grows but does not develop more than the size of pea.

A circumspect and vigilant inquiry of a disease and their host plants pertaining to their aggregate environment as well as discussion of various control measures as they affect each other and relate to the ecosystem of the organism has lately been given increasing concentration. The host resistance method is compatible with other methods of control. With this dilemma in view, the present investigation is undertaken to evaluate the varietal susceptibility against malformation disease of mango. This verdict will guide the orchardists to develop an integrated management programme of the other diseases.

\section{Material and Methods}

The investigation was carried out in Nadia district under lower Gangetic West Bengal during 2004 to 2006. Twenty varieties of mango considered for this study were Dashehari, Langra, Fazli, Chousa, Mallika, Baneshan, Bangalora, Mulgoa, Neelum, Suvarnrekha, Alphonso, Kesar, Mankurad, Fernandin, Vanraj, Zardalu, Bombai, Bombay Green, Himsagar and Kishan Bhog. Six young plants of each taxon of three to five years of bearing age are selected and allowed 
for natural infection. Screening of varieties is done during the reproductive stage in peak period of flowering i.e. during spring-summer months. All the panicles of each plant of each taxon are observed carefully and the infected panicles are counted accordingly. The yearly mean data along with pooled data of three year-long study are presented in this treatise. Plant reaction against floral malformation was measured using 0 to 5 scale (vide Table 1). The various reactions of the host-taxa to the pathogen are grouped into the following types: $0=$ highly resistant, $1=$ resistant, $2=$ moderately resistant, $3=$ moderately susceptible, $4=$ susceptible and $5=$ highly susceptible.

The data collected from the study are subjected to statistical analysis appropriate to the completely randomised design. The replicated mean data are calculated from three years of observation. The data obtained are analyzed by the analysis of variance method as suggested of Panse and Sukhatme (1989) and Gomez and Gomez (1983). Angular transformed values are mentioned in the parenthesis.

\section{Results and Discussion}

The results (vide Table 2) of survey has revealed that among the commercial varieties significantly highest percentage of infection is recorded in Mallika (46.00\%) than all other varieties except Kesar (43.60\%) and Suvarnrekha $(41.70 \%)$ and meaningfully least of that is noticed in Kisan Bhog $(2.40 \%)$ than all other varieties except Bombai,
Zardalu and Bombay Green. There is no total resistant or immune variety expressing no visible sign with PDI range 0.00 and rating scale 0 . There are 18 varieties viz., Kishan Bhog, Bombai, Zardalu, Bombay Green, Mankurad, Baneshan, Langra and Fernandin showed high resistance with expressing very low symptoms of floral malformation with PDI range below 5.0 and rating scale 1. There are three moderately resistant varieties viz., Fazli, Himsagar and Vanraj expressing low symptoms of floral malformation. There are another three moderately susceptible varieties viz., Bangalora and Mulgoa expressing intermediate symptoms of disorder. There are there susceptible varieties viz., Dashehari, Alphonso and Chousa expressing high symptoms of the malady. The order of susceptibility of mango varieties to floral malformation in descending order is Mallika, Kesar, Suvarnrekha, Dashehari, Alphonso, Chousa, Neelum, Bangalora, Mulgoa, Vanraj, Himsagar, Fazli, Fernandin, Langra, Baneshan, Mankurad, Bombay Green, Zardalu, Bombai and Kishan Bhog. Table 3 shows the summary of total number of varieties in different scores against floral malformation during the study in Gangetic West Bengal. It is also revealed that out of twenty, not a single variety is free from the malady, although Zardalu and Kishan Bhog show no visible sign of infection in the initial year of observation (2004).

This variation in the disease intensity among varieties having different levels might be attributable to the interaction of the host genotype to the pathogen.

Table 1. Mango Floral Malformation Susceptibility Rating

\begin{tabular}{|c|c|c|c|}
\hline Scale & Range of panicle infected (per cent) & Symptoms expressed & Reactions \\
\hline 0 & 0.00 & No visible symptom & Total resistant/ Immune \\
\hline 1 & $0.10-5.00$ & Very low & High resistant \\
\hline 2 & $6.00-10.00$ & Low & Moderately resistant \\
\hline 3 & $11.00-20.00$ & Intermediate & Moderately susceptible \\
\hline 4 & $21.00-40.00$ & High & Susceptible \\
\hline 5 & $41.00-100.00$ & Very high & Highly susceptible \\
\hline
\end{tabular}


Table 2. Evaluation of mango varieties against the incidence of floral malformation during 2004-2006 in Gangetic West Bengal

\begin{tabular}{|c|c|c|c|c|c|c|c|c|c|c|c|c|}
\hline \multirow{3}{*}{$\begin{array}{c}\text { Sl. No. } \\
1 .\end{array}$} & \multirow{3}{*}{$\begin{array}{c}\text { Variety } \\
\text { Dashehari }\end{array}$} & \multicolumn{6}{|c|}{ Mean per cent Infection } & \multicolumn{2}{|c|}{ Overall Mean } & \multirow{3}{*}{$\begin{array}{c}\text { Rating Scale } \\
4\end{array}$} & \multirow{3}{*}{$\begin{array}{c}\begin{array}{c}\text { Symptom } \\
\text { Expressed }\end{array} \\
\text { High }\end{array}$} & \multirow{3}{*}{$\begin{array}{c}\text { Rank } \\
4\end{array}$} \\
\hline & & \multicolumn{2}{|c|}{2004} & \multicolumn{2}{|c|}{2005} & \multicolumn{2}{|c|}{2006} & & & & & \\
\hline & & 21.30 & $(27.49)$ & 25.80 & $(30.53)$ & 24.60 & (29.73) & 23.90 & $(29.27)$ & & & \\
\hline 2. & Langra & 3.90 & $(11.39)$ & 4.50 & $(12.25)$ & 4.90 & (12.79) & 4.43 & $(12.11)$ & 1 & Very Low & 14 \\
\hline 3. & Fazli & 5.60 & $(14.69)$ & 7.10 & $(15.45)$ & 6.80 & $(15.12)$ & 6.50 & $(14.77)$ & 2 & Very Low & 12 \\
\hline 4. & Chousa & 18.70 & $(25.62)$ & 23.20 & $(28.79)$ & 24.30 & $(29.53)$ & 22.07 & $(28.04)$ & 4 & High & 6 \\
\hline 5. & Mallika & 47.50 & $(43.57)$ & 51.30 & $(45.74)$ & 39.20 & $(38.76)$ & 46.00 & $(42.71)$ & 5 & Very High & 1 \\
\hline 6. & Baneshan & 3.20 & $(10.30)$ & 4.10 & (11.68) & 5.50 & $(13.56)$ & 4.27 & $(11.97)$ & 1 & Very Low & 15 \\
\hline 7. & Bangalora & 8.50 & $(16.95)$ & 13.40 & (21.47) & 11.30 & (19.64) & 11.07 & (19.46) & 3 & Intermediate & 8 \\
\hline 8. & Mulgoa & 7.50 & $(15.89)$ & 8.30 & $(16.74)$ & 16.20 & (19.55) & 10.67 & (19.09) & 3 & Intermediate & 9 \\
\hline 9. & Neelum & 14.80 & $(22.63)$ & 13.20 & $(21.30)$ & 9.60 & $(18.05)$ & 12.53 & $(20.70)$ & 3 & Very High & 7 \\
\hline 10. & Suvarnrekha & 40.20 & $(39.25)$ & 39.70 & $(39.06)$ & 45.20 & $(42.25)$ & 41.70 & $(40.22)$ & 5 & Intermediate & 3 \\
\hline 11. & Alphonso & 21.60 & (27.69) & 23.20 & (28.79) & 22.80 & $(28.52)$ & 22.53 & $(28.32)$ & 4 & High & 5 \\
\hline 12. & Kesar & 35.40 & $(36.51)$ & 46.30 & $(42.88)$ & 49.10 & (44.48) & 43.60 & $(41.32)$ & 5 & Very High & 2 \\
\hline 13. & Mankurad & 1.90 & $(7.92)$ & 4.30 & (11.97) & 5.80 & (13.94) & 4.00 & (11.54) & 1 & Very Low & 16 \\
\hline 14. & Fernandin & 3.40 & (11.63) & 7.20 & $(15.56)$ & 3.60 & (10.94) & 4.73 & $(12.52)$ & 1 & Very Low & 13 \\
\hline 15. & Vanraj & 9.30 & (17.76) & 10.20 & $(18.63)$ & 8.70 & $(17.15)$ & 9.40 & $(17.85)$ & 2 & Very Low & 10 \\
\hline 16. & Zardalu & 0.00 & $(0.00)$ & 2.30 & $(8.72)$ & 5.50 & (13.56) & 2.60 & $(9.28)$ & 1 & Very Low & 18 \\
\hline 17. & Bombai & 2.10 & (8.33) & 3.20 & $(10.30)$ & 1.90 & $(7.92)$ & 2.40 & (8.91) & 1 & Very Low & 19 \\
\hline 18. & Bombay Green & 1.50 & $(7.03)$ & 4.90 & (12.79) & 2.60 & $(9.28)$ & 3.00 & $(9.97)$ & 1 & Very Low & 17 \\
\hline 19. & Himsagar & 8.30 & (16.74) & 6.90 & (15.23) & 9.10 & $(17.56)$ & 8.10 & (16.54) & 2 & Very Low & 11 \\
\hline \multirow[t]{3}{*}{20.} & Kishan Bhog & 0.00 & $(0.00)$ & 4.90 & $(12.79)$ & 2.30 & $(8.72)$ & 2.40 & $(8.91)$ & 1 & Very Low & 19 \\
\hline & $\mathrm{SE}(\mathrm{m})$ & \multicolumn{2}{|c|}{6.36} & \multicolumn{2}{|c|}{7.18} & \multicolumn{2}{|c|}{7.02} & \multicolumn{2}{|c|}{1.59} & & & \\
\hline & $\mathrm{CD}(0.05)$ & \multicolumn{2}{|c|}{12.85} & \multicolumn{2}{|c|}{14.52} & & & \multicolumn{2}{|c|}{4.54} & & & \\
\hline
\end{tabular}

Note: Figures in the parenthesis are angular transformed values 
Table 3. Summary of total number of varieties in different score against mango floral malformation during the study period in Gangetic West Bengal

\begin{tabular}{|c|c|c|c|c|c|c|}
\hline Score & Score 5 & Score 4 & Score 3 & Score 2 & Score 1 & Score 0 \\
\hline Reaction & $\begin{array}{c}\text { Highly } \\
\text { Susceptible }\end{array}$ & Susceptible & $\begin{array}{c}\text { Moderately } \\
\text { Susceptible }\end{array}$ & $\begin{array}{c}\text { Moderately } \\
\text { Resistant }\end{array}$ & $\begin{array}{c}\text { High } \\
\text { Resistant }\end{array}$ & $\begin{array}{c}\text { Total } \\
\text { Resistant/ } \\
\text { Immune }\end{array}$ \\
\hline $\begin{array}{c}\text { Number of } \\
\text { Variety }\end{array}$ & 3 & 3 & 3 & 3 & 8 & Nil \\
\hline $\begin{array}{c}\text { Percentage } \\
\text { of the total }\end{array}$ & 15 & 15 & 15 & 15 & 40 & 0 \\
\hline $\begin{array}{c}\text { Name of the } \\
\text { Variety }\end{array}$ & $\begin{array}{c}\text { Mallika, } \\
\text { Kesar, } \\
\text { Suvarnrekha }\end{array}$ & $\begin{array}{c}\text { Dashehari, } \\
\text { Alphonso, } \\
\text { Chousa }\end{array}$ & $\begin{array}{c}\text { Neelum, } \\
\text { Bangalora, } \\
\text { Mulgoa }\end{array}$ & $\begin{array}{c}\text { Fazli, } \\
\text { Vansagaj, }\end{array}$ & $\begin{array}{c}\text { Kishan Bhog, } \\
\text { Bombai, Zardalu, } \\
\text { Bombay Green, } \\
\text { Mankurad, } \\
\text { Baneshan, Langra, } \\
\text { Fernandin }\end{array}$ & \\
\hline
\end{tabular}

\section{Conclusion}

Twenty mango varieties are evaluated for tolerance against floral malformation during 2004 to 2006 in Gangetic West Bengal. It is found that among the commercial varieties, Mallika is the most susceptible taxon for tolerance against floral malformation and Kishan Bhog is the least. On average maximum varieties attain the rating scale (score)- 1 which signifies very low infection or high resistant reaction for tolerance against floral malformation. Lahav et al. (2001) observed that the initial number of infected trees and trees with 2 or more flowers were 86 and $38 \%$ respectively. In 1999 , the number of infected trees rose to $97 \%$, while the percentage of infected trees with 2 or more flowers dropped to $20 \%$. In 2000 , the number of infected trees was reduced to $34 \%$, while the number of infected trees with 2 or more flowers decreased to $3 \%$. The more or less reverse observation is found in three year-long studies where the percentage of infected panicles are increased with respect to the initial year. Sant Ram et al. (1998) mentioned factors affecting the susceptibility of mango cultivars to malformation. In this context, it may be noted that Chakraborti et al. (2007) screened several mango hybrids for tolerance against leaf cutting weevil (Deporaus marginatus Pascal) and found out suitable pest tolerant taxon Prabha Sankar is new alluvial zone of West Bengal. Mango germplasm comprising of forty three varieties was evaluated by Hafiz et al. (2008) for the level of the panicle malformation disease intensity. Out of tested varieties, four were tolerant, 27 were moderately tolerant, five were moderately susceptible while seven were recorded highly susceptible to malformation. Disease incidence frequency was highest in 'Lab-e-Mashooq' (68.70\%) followed by 'G.M.Wala' (64.28\%) and lowest in 'Sensation' (7.20\%) and 'Gulab Khas' (7.8\%). However, use of resistant root stocks or cultivars can be effective measures to control these diseases (Verma and Sharma, 2005).

\section{REFERENCES}

[1] Ahmad, F., Hafiz, I.A., Asi, A.A., Ahmad, S. and Khan, M. 2002. Mango varietal susceptibility to malformation and its control. Asian J. Plant Science 1(2):158-159.

[2] Chakraborti, K. 2006. Studies in the diversities in different varieties of Mangifera indica L. in Gangetic West Bengal. Unpublished Ph.D. thesis, University of Kalyani: 127-130.

[3] Chakraborti, K., Sen, T., Samanta, S. K. and Pal Choudhury, J. 2007. Screening of mango hybrids for tolerance against leaf cutting weevil in new alluvial zone of West Bengal. Journal of Interacademicia 11 (4) [In Press]

[4] Ginai, M. A. 1965. Malformation of mango inflorescence (West Pakistan). Journal of Agril Res. 3: 248-251.

[5] Gomez, K. A. and Gomez, A. A. 1983. Statistical procedures for agricultural research. John Willey \& Sons. New York: 20-29.

[6] Hafiz, I.A., Ahmad, S., Abbasi, N.A., Anwar, R., Chatha, Z.A. and Grewal, A.G. 2008. Intensity of panicle malformation in mango (Mangifera indica L.) varieties. Pak. J. Agri. Sc., 45(4):418-423.

[7] Lahav, C., Sztejnberg, A., Maymon, M., Danisov. Y. and Freeman, S. 2001. Mango malformation disease: presence and identification of the causal organism Fusarium subglutinans in main branches of mature trees and saplings grafted with infected scions, and importance of sanitation treatments in orchards. Alon-Hanotea. 55 (7): 301-304.

[8] Panse, V. G. and Sukhatme, P. V. 1989. Statistical methods for agricultural workers. ICAR. New Delhi: 97-128.

[9] Ploetz, R.C. 2001. Malformation: a unique and important disease of mango, Mangifera indica L. In: B.A. Summerell, J.F. Leslie, D. Backhouse, W.L. Bryden, L.W. Burgess (Eds.) Fusarium: Paul E. Nelson Memorial Symposium. St. Paul, MN: APS Press: 233-247.

[10] Rao, Madhavan 1983. The Statesman, New Delhi, Oct. 15th.

[11] Sant Ram, Ram, S. and Singh, R. 2001. Mango malformation. Indian Journal of Horticulture. 58 (1-2): 78-90.

[12] Verma, K. S. and Sharma, A. 2005. Challenging disease problems in subtropical fruits and their management. In: Challenging problems in horticultural and forests pathology: 72-89.

[13] Watt, G. 1891. Dictionary of the economic products of India, 5: 149 . 